\title{
COTIDIANO
}

\section{EGO E INCOMPLETUDE}

Afonso Celso L. Wanderley(1)

Ao ego, será sempre impossível a plenitude! Como “filho legítimo” da Grande Separação, do surgimento do "eu separado”, do Adão (que vem do sânscrito: adhi-aham = “primeiro eu”), sempre lhe faltará Algo - pois ele sofre a perda da identidade com o Todo, desde que diferenciou-se dessa matriz primordial, ontológica, representada inicialmente no psiquismo individual pelo útero materno e, logo após, pela relação simbiótica e edipiana com a figura materna. E em busca desse Algo ele tece desde o nascimento uma teia de incontáveis desejos na esperança inconsciente de sustentar-se sobre o imenso vazio existencial, num desespero inaudível de busca de sobrevivência e de auto-justificativa para o devir dessa existência.

E ele (o ego), se esforça laboriosamente através da vigília e através do sono para satisfazer a cada um de seus desejos, ora justificando-os como instintos naturais e intransponíveis, ora vestindo-os em trajes mais nobres, como algum bem social, moral, científico ou até mesmo espiritual.

E nessa incessante luta para aplacar a angústia existencial de uma Falta irreparável, o ego finalmente começa a mostrar sinais de cansaço, extenuado pelos inúmeros chamados e tensões gerados pela teia de seus próprios desejos.

E então surgem as "técnicas de sobrevivência” para o claudicante ego. Sistemas de resignificação, reprogramação, regressão, re-elaboração, relaxamento. Terapias alternativas, homeopáticas, alopáticas, hipnóticas e florais, para atenuar a dor da Grande Falta, para evitar o desespero do confrontamento com o Vazio - com “o deserto do Real”. Todas essas técnicas fornecem alguma nova habilidade de sobrevivência ao ego, mas será sempre o ego o sobrevivente e sujeito do (ou ao) processo, por mais sutil que possa ser sua forma. São portanto "variações de um mesmo tema”, e não trarão jamais a plenitude sonhada pelo ego, porquanto é o mesmo ego que continuará aí, incompleto e carente. 
Como ajudar o ego a aceitar sua real condição - ilusória, impermanente, presa ao infindável ciclo dos desejos -, e o seu terrível destino - a morte e dissolução em um futuro não muito distante? Como ajudá-lo a buscar uma relação mais consciente e livre com todos os desejos e prazeres que lhe são tão queridos?

Somente a vivência exaustiva dos próprios desejos e a conseqüente percepção decepcionante da repetição interminável de seu ciclo pode fazer o ego abdicar do desejo - seja por objetos físicos, emocionais, mentais ou espirituais. Será, entretanto, necessário não se tornar cínico diante dessa realidade (aceitando-a como uma condição existencial intransponível), nem fascinado pelas infinitas possibilidades de metamorfose do ego e de suas criações.

Além disso, haverá sempre a atraente e perigosa sugestão de que será possível chegar à Plenitude carregando todos os nossos desejos, nossas “queridas” e seguras maneiras de ser.

Sim, seria dado um grande passo se estivéssemos inteiramente conscientes da incompletude e impermanência intrínsecas do ego e seus desejos, de sua total incapacidade de tornar-se lugar de felicidade permanente. Isso dissolveria naturalmente todas as falsas soluções, todos os falsos poderes engendrados por nosso desespero desejante. Para esse passo, muito pode nos ajudar o Bhagavad Gita de Krishna, o ensinamento de Buda, a mensagem essencial do Evangelho (distinguindo bem esse Evangelho de toda máquina institucional, política e econômica das religiões que abraçaram sua mensagem) e as grandes aproximações do Ocidente aos mistérios da alma: a Psicanálise de Freud, a Psicologia Analítica de Jung, a Psicologia Transpessoal de Stanislav Groff e de Ken Wilber.

Um outro grande passo seria dado se aprendêssemos a desaprender tudo o que vimos no passo anterior, a desapegar-se da segurança do conhecido, a cultivar uma permanente, atenta e alegre abertura ao Novo, ao Surpreendente, sem deixar-se fascinar pelos seus encantos e sem, no entanto, ser indiferente a eles...

Porém, ao primeiro desses “dois passos” reage com todas as forças o ego humano, apoiado nos sedutores argumentos que sua interminável teia de paixões engendra a cada instante e na sua inerente necessidade de sobrevivência... “Como”, diz ele, "viver sem desejar e sem apaixonar-se pelo objeto desse desejo?!”...

E ao segundo passo resiste de forma sutil - porém quase intransponível - o último reduto de nossa consciência pessoal, sua forma mais profunda e poderosa de identificação, que se manifesta através da aderência a um conhecimento ou sistema de pensamento, à beleza e harmonia de um conjunto de idéias laboriosamente construído ao longo da vida, sempre 
respaldado pela interpretação parcial e tendenciosa dos fenômenos observados - o "apego noético”.

“O homem ama o sofrimento e protege paternalmente sua dor...”, diz Sri Aurobindo. Talvez porque mesmo através dessa dor ele esteja buscando uma prova da realidade de sua própria existência - “Sofro, logo existo!”, parece ser sua lógica.

(1) Afonso Celso L. Wanderley é Professor da UNIPAZ - Universidade Holística Internacional. Membro do GET - Grupo de Estudos Transdisciplinares no Núcleo Recife. 